\title{
Hazard and Risk Analysis for Ring Spinning Yarn Production Process by Integrated FTA-FMEA Approach
}

\author{
Nazlı Gülüm Mutlu, Serkan Altuntaş \\ Department of Industrial Engineering, Yildiz Technical University, Istanbul, Turkey
}

Corresponding Author: Nazlı Gülüm Mutlu,ngmutlu@yildiz.edu.tr

\begin{abstract}
The hazard analysis and management is vital in textile industry to avoid losing customers and wasting resources caused by the failures in production systems. Risk analysis is also very significant to decrease possible hazards and to avoid possible damage in production systems. In this study, an approach based on Failure Mode and Effects Analysis (FMEA) and Fault Tree Analysis (FTA) is proposed to analyze the ring spinning yarn production process in a textile industry. First, the possible hazards in the production line, yarn production system, in an integrated company operating in the textile sector are analyzed by FTA method. Then, FMEA is applied to ring spinning yarn production process in a textile industry to rank all possible risks corresponding to hazards in descending order with respect to both occupational health and safety. It is very important to remove all possible hazards in textile industry to decrease the number of risks related to occupational health and safety. Therefore, in total of 57 hazard root causes are determined in the yarn production department. Subsequently, the faults related to the hazard root causes are examined by FTA and then risk corresponding to these hazards are prioritized by FMEA. The results obtained from the proposed FTA-FMEA approach show that decision makers and engineers can easily decrease the number of hazards and risks with respect to both occupational health and safety in practice.
\end{abstract}

\section{ARTICLE HISTORY}

Received: 13.11 .2018

Accepted: 25.06.2019

\section{KEYWORDS}

FMEA, FTA, Risk and hazard analysis, Production system, Ring spinning yarn, Textile industry

\section{INTRODUCTION}

Reducing the failures and hazards is crucial for a company to maintain their position on the market, to increase their competitiveness in the market, and to contribute to the country's economic development. The failure and hazard management is known to reduce the defects in the production system, to increase the effective use time of the machines and the equipment, to decrease customer complaints and to increase productivity [1]. Analyzes of production process and improvement of processes efficiency in the textile industry are also important to increase the competitiveness of firms [2, 3]. Güner and İşler [4] examined the effect of equipment conditions on process efficiency. Burduk and Krenczyk [5] pointed out that the potential risks in production systems must be managed to ensure effective management of enterprises. The focus of the risk management is to identify hazards associated with functional units and their components, to estimate and evaluate the risks, and to carry out activities to prevent risks and their constant control [6]. Peddada [7] and Hiles [8] emphasized that risk management performance is important to ensure business continuity and is an indicator for the success of management. The quality of textile products is directly related to yarn quality. Yarn quality also depends on the production conditions. In order to improve yarn quality in the literature, many number of studies have been conducted to optimize production conditions [9-14]. Küçük and Güner [2] analyzed the efficiency value of firms in the textile industry by using fuzzy logic approach and ranked criteria that have impact on efficiency value. Also, synthetic fiber and cotton are the most basic substances for textile products. However, the life cycle of synthetic fibers and cotton has a negative impact on the environment [15]. Therefore, it is obvious that the present fiber or cotton

To cite this article: Mutlu NG, Altuntaş S. 2019. Hazard and risk analysis for ring spinning yarn production process by integrated FTAFMEA approach. Tekstil ve Konfeksiyon 29(3), 208-218. 
should be used in the least-loss manufacturing. Therefore, it is necessary to analyze the production processes, to define hazards and to take necessary measures. One of the leading sectors in Turkey is textile sector. It has an important role in Turkish economy as it creates new job opportunities and contributes to the development of the economy [16, 17]. Analyzing the factors that threaten the sustainability the development of textile sector is very important due to its effect on quality of the products and reduction of production loss [18].

There are also risks that threaten occupational health and safety in the textile industry. Malik et al. [19] pointed out that there are many risks related to workers in the textile industry, such as physical, chemical, biological, and determined the role of hazards control measures in Occupational Health and Safety (OHS) in textile industry. Khan et al. [20] focused on the occupational health and safety in the textile industries of Lahore as well.

In literature, studies, which examined textile production conditions, have basically focused on optimization. But, there are limited number of studies, which has been focused on definition and classification of hazards in the ring spinning yarn process. Therefore, in the present study, the hazards in the ring spinning production facility of an enterprise in the textile sector is analyzed and risks corresponding to these hazards are ranked by using FTAFMEA approach. It is believed that the results obtained from FTA-FMEA approach provided useful information to reduce losses and prevent failures and hazards.

\section{LITERATURE REVIEW}

The potential risks in production systems can be mainly caused by failures and hazards due to the material, human, production measurement method and machines/equipment. The risk analysis and evaluation methods with top-down or bottom-up approaches can be evaluated to reduce the risks in the systems. In the literature, hazard and risk analysis methods are used to define undesirable events and their status in production systems. What-If [21], Checklist [21, 22], Preliminary hazard analysis (PHA) [21, 23, 24], Fault tree and Event tree analysis (FTA) [22, 24], Subsystem hazard analysis (SSHA) [24], System hazard analysis (SHA) [24] are some of the methods used for hazard analysis. Furthermore, Failure Mode and Effect Analysis (FMEA) [6, 25, 26], Hazard and Operability (HAZOP) [6, 26], Human reliability analysis (HRA) [22], Probabilistic risk assessment (PRA) [24] are extensively used for risk analysis in production systems.

FMEA method is one of the well-known method and it is used for the identification of possible hazard types in various areas of the textile sector, taking precaution for eliminating hazards or reducing their effects to improve process performance in the literature. Beyene et al. [27] implemented FMEA to identify defects that led to production stoppages in a textile firm, found out that stoppage time can be reduced and the productivity can be increased. Küçük et al. [28] identified the failure modes in the laying and cutting process in the clothing sector by using FMEA tool. Paired et al. [29] used the FMEA method to detect garment manufacturing defects and to develop a quality control system and then to analyze the optimization of production efficiency using a simulation-based optimization technique. Kumar et al. [30] analyzed the processing failures affecting the process by using FMEA method in addition to value streaming analysis and Kaizen tools to reduce the cycle time of T-shirt production. Kaewsom and Rojanarowan [31] conducted the FMEA study to reduce the failure of the broken filament in the direct spinning process. Özyazgan [32] conducted FMEA analysis and implementation in a textile factory producing woven fabric. Peddada [7] categorized risks as business risk, control risk, opportunity risk and personal risk and stated that they are used in FMEA method in the evaluation of the risks.

In addition, Liu et al. [33] reported the major shortcomings of FMEA based on literature review. They are given in the following [33]:

1. The relative importance among $\mathrm{O}, \mathrm{S}$ and $\mathrm{D}$ is not taken into consideration.

2. Different combinations of $\mathrm{O}, \mathrm{S}$ and $\mathrm{D}$ may produce exactly the same value of RPN, but their hidden risk implications may be totally different.

3. The three risk factors are difficult to be precisely evaluated.

4. The mathematical formula for calculating RPN is questionable and debatable.

5. The conversion of scores is different for the three risk factors.

6. The RPN cannot be used to measure the effectiveness of corrective actions.

7. RPNs are not continuous with many holes.

8. Interdependencies among various failure modes and effects are not taken into account.

9. The mathematical form adopted for calculating the RPN is strongly sensitive to variations in risk factor evaluations.

10. The RPN elements have many duplicate numbers.

11. The RPN considers only three risk factors mainly in terms of safety.

The FMEA may be insufficient to identify hazards due to the fact that it focus on failure mode [24]. In this study, integrated FTA-FMEA approach is used to identify hazards and to focus on failure modes.

There are also studies using FTA and FMEA methods together in the literature [34-37]. Martins and Gorschek [38] deeply analyzed the root causes of the failures by applying the FTA for the critical failures after ranking failure types carrying out an FMEA study for the safetycritical systems. 
The literature review revealed that the FMEA and FTA methods have been determined to be a useful method and frequently used for failure analysis for the systems and their components and ranking the risk potentials of the failures. For this reason, the FTA and FMEA methods have been integrated and used in order to analyze the hazards in the ring spinning yarn production of a company operating in the textile sector within the scope of this study.

\section{MATERIAL AND METHOD}

\subsection{Materials}

In this study, the FTA-FMEA application has been implemented for a ring spinning yarn production of a company operating in the textile sector. There are 20 ring spinning machines with 1,200 spindles in the ring spinning facility. The annual ring spinning production capacity of the company is 5,000 tons $(90 \%$ combed cotton and $10 \%$ carded). The blow room, foreign matter control, carding, draw-frame, the wadding preparation, wadding transfer, combed cotton, cording, ring, coil, mobile cleaner, fixation, coil winding, bale-opening, needle opening, electromagnet mixer, condenser, feeding unit, and fine opening machines are used in ring spinning facility.

\subsection{Methods}

\subsubsection{Failure Mode and Effect Analysis (FMEA)}

The FMEA method is a systematic approach used to identify and prevent failures in the product and the production processes before they occur. It identifies the failures with a bottom-up approach [1]. FMEA uses three important inputs, namely the Occurrence (O), Severity (S) and Detectability (D), related to potential hazards/failures in a system, design, process, or equipment and to provide an input for mitigation measures to mitigate risk [6, 25]. For FMEA application, the information on system structure, defining system boundary for the analysis, and the level of analysis and analysis procedure are available at IEC 61812: 2006. Also, some of the terms used in the method are as follows [25].

Item: Any part, component, device, subsystem, functional unit, equipment or system that can be individually considered.

Failure: Termination of the ability of an item to perform a required function.

- Failure mode: Manner in which an item fails.

Failure effect: Consequence of a failure mode in terms of the operation, function or status of the item.

Failure severity: Failure mode effect severity as related to the defined boundaries of the analyzed system.

> System: Set of interrelated or interacting elements.

The Risk Priority Number (RPN) is calculated as shown in Equation 1,

$\mathrm{RPN}=(\mathrm{O}) \mathrm{x}(\mathrm{S}) \mathrm{x}(\mathrm{D})$

where, $O$ denotes occurrence which implies the probability of occurrence of a failure mode for a predetermined or stated time period, $D$ means detectability, i.e. an estimate of the chance to identify and eliminate the failure before the system or customer is affected and $S$ is a non-dimensional number that stands for severity, i.e. an estimate of how strongly the effects of the failure will affect the system or the user [25]. Classification of RPN is given in Table 1.

FTA method is a hazard analysis and evaluation method using a top-down approach and it also allow showing the diagrams of the logical relationship between the root causes of the possible hazards and the top event due to those root causes [7]. The FTA method is used to describe the multiple hazards conditions that cause two or more events that lead the occurrence of the top event. The logic gate symbols and the event symbols are given in Table 2 .

\subsubsection{Fault Tree Analysis (FTA)}

The logic gate symbols and the event symbols are frequently used in establishing logical relationships between the root causes of the hazards. Also, some of the terms used in the method are as follows [39].

Table 1. Classification of RPN

\begin{tabular}{cc}
\hline Classification & RPN \\
\hline Intolerable & $>201$ \\
High & $101-200$ \\
Moderate & $51-100$ \\
Tolerable & $1-50$ \\
\hline
\end{tabular}

\subsubsection{Integration of FTA and FMEA Methods}

In this study, the FTA and FMEA methods have been integrated and used to analyze the failures in the production system, to determine the root causes, and to rank them. The proposed FTA-FMEA approach is given in Figure 1. As can be seen from Table 2, there are 2 logic gates and 4 event symbols. Step 6 and Step 7 are related to FTA. Furthermore, the remaining steps except for Step 6 and Step

Table 2. Logic gate symbols and event symbols [7]

\begin{tabular}{cclccl}
\hline $\begin{array}{c}\text { Gate } \\
\text { Symbol }\end{array}$ & $\begin{array}{c}\text { Gate } \\
\text { Name }\end{array}$ & Causal Relation & $\begin{array}{c}\text { Event } \\
\text { Symbol }\end{array}$ & Event Name & Meaning \\
\hline AND & $\begin{array}{l}\text { Output event occurs if all input } \\
\text { events occur simultaneously } \\
\text { OR } \\
\text { the input events occurs }\end{array}$ & CIRCLE & $\begin{array}{l}\text { Basic event with sufficient } \\
\text { data }\end{array}$ \\
OR & $\begin{array}{l}\text { DEAMOND } \\
\text { Undeveloped event } \\
\text { TRIANGLE }\end{array}$ & $\begin{array}{l}\text { Event represented by a gate } \\
\text { Transfer symbol }\end{array}$ \\
\hline
\end{tabular}




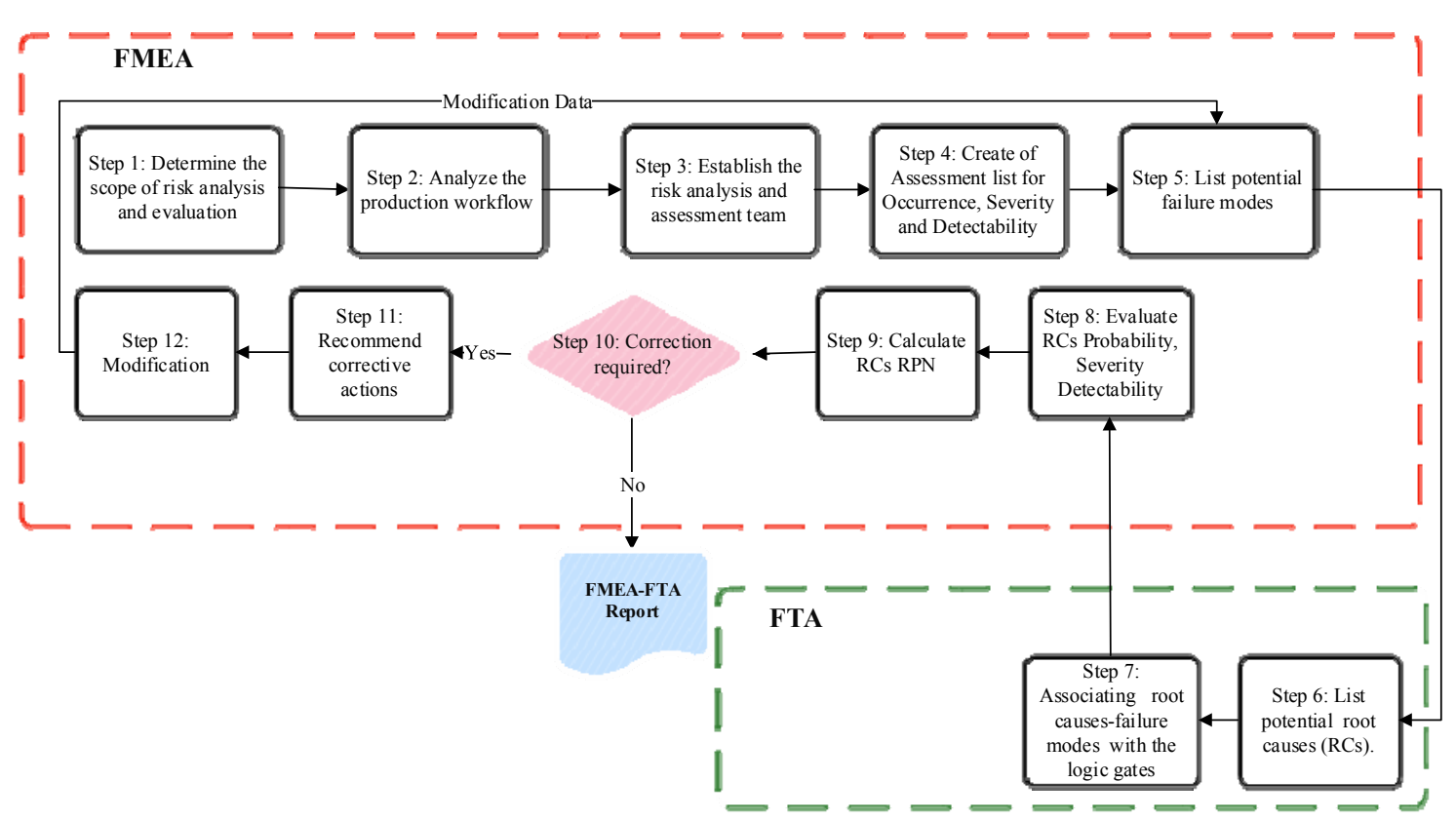

Figure 1. The proposed FTA-FMEA approach.

Table 3. The experts interviewed to obtain the failure information in the ring spinning department

\begin{tabular}{llc}
\hline Branch & Department & Experience (year) \\
\hline Mechanical Engineering & Ring Spinning Manager & 20 \\
Mechanical Engineering & Ring Spinning Production Chief & 10 \\
Mechanical Engineering & Ring Spinning Maintenance Chief & 2 \\
OHS Specialist & Plant Manager & 10 \\
\hline
\end{tabular}

7 are related to the FMEA. The steps belong to FMEA calculate the RPN of the potential failures, while the steps belong to FTA identify the potential root causes and find the associations between root causes and failure modes.

The benefit of an integrated analysis are the following [39]:

$>$ FTA is a top-down and FMEA a bottom-up analysis method and use of both deductive and inductive reasoning is regarded as a good argument for providing assurance for the completeness of an analysis;

$>$ Safety standards often demand a single failure and, in some cases, a multiple failure analysis, the first requirement being fulfilled by FMEA. Both single and multiple failure analysis are accomplished by FTA;

$>$ FMEA is also a useful method for a comprehensive identification of basic events or risks, while FTA is a practical method for causal analysis of the undesirable events or hazards.

\section{RESULT AND DISCUSSION}

A total of 57 failure root causes have been identified in the ring spinning production facility. These faults are classified in three main categories as the failures that decrease the quality of the yarn and increase the cost by adversely affecting the production process, the machine failures that lead to halts in the production, and the hazardous situations that can cause a fire in the facility. Ring spinning yarn production workflow is given in Figure 2. Figure 3 shows the result of FTA for ring spinning production operation. Ring spinning yarn production workflow is taken into account to identify failure modes in the ring spinning process (See Figure 1). The experts given in Table 3 are interviewed to obtain the failure information in the ring spinning department. Table 4, Table 5 and Table 6 are used for evaluation criteria. The Occurrence $(\mathrm{O})$ value, Severity (S) value and Detection value (D) for the each root causes are given in Table 8 . The root causes of failure are ranked based on the experts' evaluations. Twenty-two different RPN values ranging from 16-900 have been obtained for 57 root causes of the failures determined for the ring spinning facility. The possible failure modes and the root causes of the failures of the ring spinning facility are described in Table 7. The rankings of the identified failures are shown in Table 9. It has been determined that $22.80 \%$ of the identified failures were intolerable, $15.78 \%$ were high, $28.07 \%$ were moderate, and $37.35 \%$ were tolerable.

\section{CONCLUSION}

An approach based on FTA and FMEA is proposed to analyze hazard and risk analysis for ring spinning yarn production process. In the first stage of the proposed approach, possible root causes are determined and casual 
relations among hazards are found by FTA. There main possible hazards (production process failures, machines failure and fire failure related to occupational health and safety) are defined related to the process under concern. Then, FMEA is utilized to rank risks. The results of the case study show that $60 \%$ of failures related to production process and $46.66 \%$ of failures related to fire are risky at intolerable level, while failures related to machines are risky at moderate level in ring spinning yarn production process in the textile factory. In addition, the results of this study show that failures are occurred due to at least one root cause. It is necessary to take action plans to prevent these failures in the production system. Especially, the failures having the highest RPN should be eliminated from root causes in the ring spinning process. If the elimination of the failures are not possible, the RPN of these type failures should be decreased at an acceptable level. In addition, total productive maintenance policies should be applied to ring spinning yarn production process to remove all failures related to machine in practice.

Fuzzy logic can be used for the risk analysis in the future research.

Table 4. The Occurrence related to frequency and probability of occurrence [25]

\begin{tabular}{cccc}
\hline Rating & Occurrence & Frequency & Probability \\
\hline 10 & Very High: Inevitable failure & $>100$, per thousand operations & $\geq 10^{-1}$ \\
9 & & 50, per thousand operations & $5 \times 10^{-2}$ \\
8 & High: Inevitable failure & 20 , per thousand operations & $2 \times 10^{-2}$ \\
7 & & 10 , per thousand operations & $1 \times 10^{-2}$ \\
6 & Moderate: Occasional failure & 5, per thousand operations & $5 \times 10^{-3}$ \\
5 & & 2, per thousand operations & $2 \times 10^{-3}$ \\
4 & & 1, per thousand operations & $1 \times 10^{-3}$ \\
3 & Low: Relatively few failure & 0.05, per thousand operations & $5 \times 10^{-4}$ \\
2 & Remote: Failure is unlikely & 0.1, per thousand operations & $1 \times 10^{-4}$ \\
1 & & $<0.001$, per thousand operations & $\leq 1 \times 10^{-5}$ \\
\hline
\end{tabular}

Table 5. The severity evaluation criteria [25]

\begin{tabular}{clc}
\hline Severity & Criteria & Ranking \\
\hline Hazardous & Very high severity ranking when a potential failure mode affects safe vehicle operation and/or & 10 \\
without warning & involves non-compliance with government regulation without warning. & \\
Hazardous with & Very high severity ranking when a potential failure mode affects safe vehicle operation and/or & 9 \\
warning & involves non-compliance with government regulation with warning. & 8 \\
Very high & Vehicle/item inoperable (loss of primary function). & 7 \\
High & Vehicle/item operable but at a reduced level of performance. & 6 \\
Moderate & Vehicle/item operable but comfort/convenience item(s) inoperable. \\
Low & Vehicle/item operable but comfort/convenience item(s) operable at a reduced level & 5 \\
Very low & Fit performance. & 4 \\
Minor & Fit and finish/squeak and rattle item does not conform (greater than 75\%). & 3 \\
Very minor & Fit and finish/squeak and rattle item does not conform (approximately 50\%). & 2 \\
None & No discernible effect. & 1 \\
\hline
\end{tabular}

Table 6. The detection evaluation criteria [25]

\begin{tabular}{|c|c|c|}
\hline Detection & Criteria: Likelihood of detection & Ranking \\
\hline Absolutely uncertain & $\begin{array}{l}\text { Process Control will not and/or cannot detect a potential cause/mechanism and subsequent } \\
\text { failure mode; or there is no Process Control. }\end{array}$ & 10 \\
\hline Very remote & $\begin{array}{l}\text { Very remote chance the Process Control will detect a potential cause/mechanism and } \\
\text { subsequent failure mode. }\end{array}$ & 9 \\
\hline Remote & $\begin{array}{l}\text { Remote chance the Process Control will detect a potential cause/mechanism and subsequent } \\
\text { failure mode. }\end{array}$ & 8 \\
\hline Very low & $\begin{array}{l}\text { Very low chance the Process Control will detect a potential cause/mechanism and subsequent } \\
\text { failure mode. }\end{array}$ & 7 \\
\hline Low & $\begin{array}{l}\text { Low chance the Process Control will detect a potential cause/mechanism and subsequent failure } \\
\text { mode. }\end{array}$ & 6 \\
\hline Moderate & $\begin{array}{l}\text { Moderate chance the Process Control will detect a potential cause/mechanism and subsequent } \\
\text { failure mode. }\end{array}$ & 5 \\
\hline Moderately High & $\begin{array}{l}\text { Moderately high chance the Process Control will detect a potential cause/mechanism and } \\
\text { subsequent failure mode. }\end{array}$ & 4 \\
\hline High & $\begin{array}{l}\text { High chance the Process Control will detect a potential cause/mechanism and subsequent } \\
\text { failure mode. }\end{array}$ & 3 \\
\hline Very high & $\begin{array}{l}\text { Very high chance the Process Control will detect a potential cause/mechanism and subsequent } \\
\text { failure mode. }\end{array}$ & 2 \\
\hline Almost certain & $\begin{array}{l}\text { Process Control will almost certainly detect a potential cause/mechanism and subsequent } \\
\text { failure mode. }\end{array}$ & 1 \\
\hline
\end{tabular}




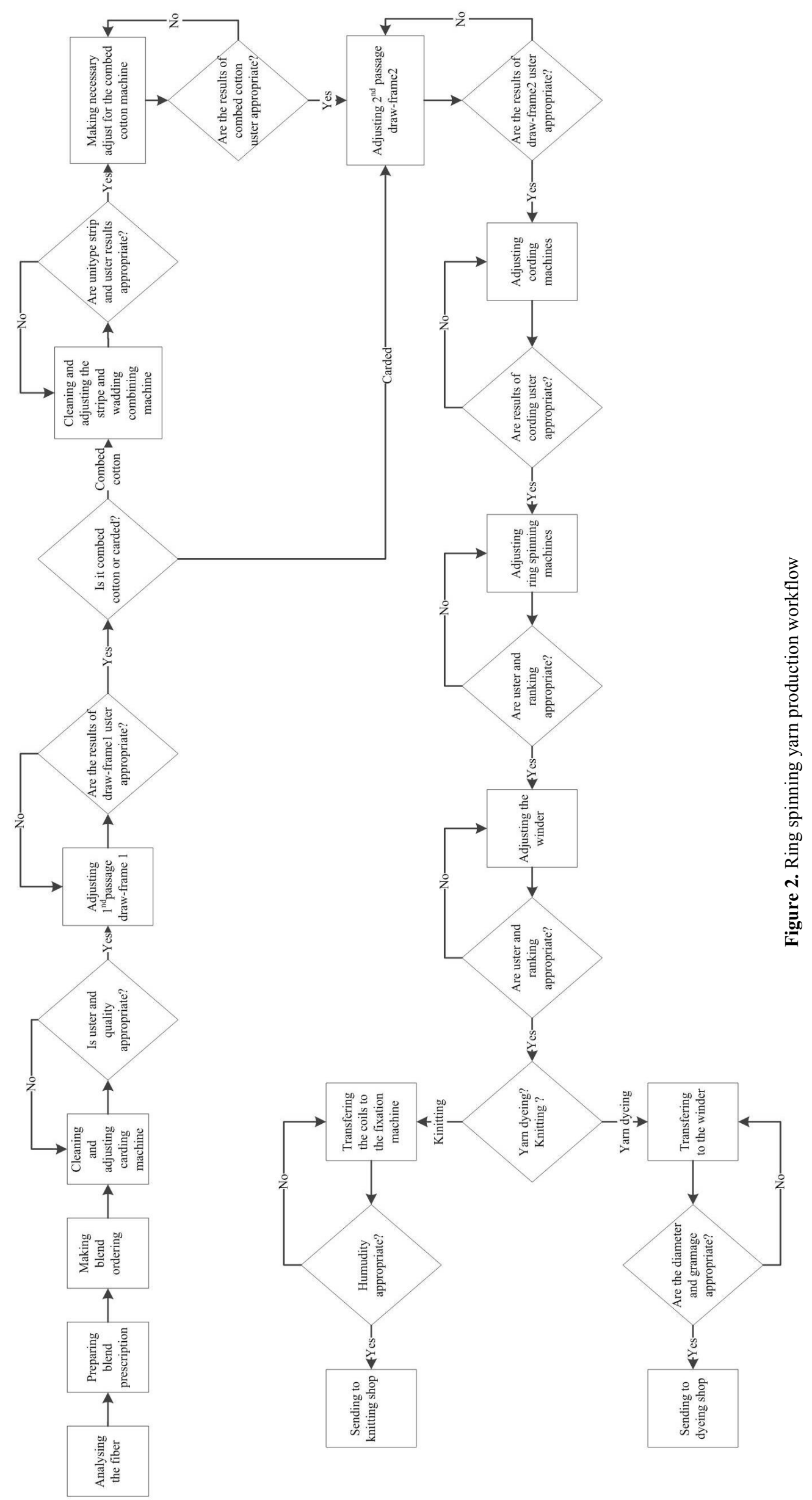


Table 7. The possible failure modes and the root causes for the ring spinning yarn production process

\begin{tabular}{|c|c|c|c|}
\hline Function & Failure Mode & Root Cause of the Failure & $\mathbf{F M}_{\mathrm{i}}^{\mathrm{j}}$ \\
\hline \multirow{10}{*}{ 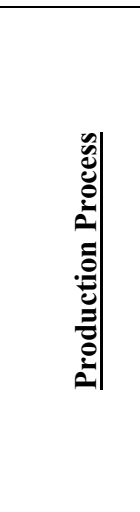 } & \multirow{4}{*}{ Abrage } & Blend prescription not prepared correctly & $\mathrm{FM}_{1}{ }^{1}$ \\
\hline & & The ordering of fiber bundles incompliant with the blend prescription & $\mathrm{FM}_{1}^{2}$ \\
\hline & & $\begin{array}{l}\text { Not arranging the carding buckets under the draw-frame in accordance with the } \\
\text { desired plan }\end{array}$ & $\mathrm{FM}_{1}^{3}$ \\
\hline & & Blending differences & $\mathrm{FM}_{1}^{4}$ \\
\hline & \multirow{2}{*}{ Incorrect yarn number } & Not setting the yarn number to the machine & $\mathrm{FM}_{2}{ }^{1}$ \\
\hline & & Failure of the regulation system in the regulated draw-frames & $\mathrm{FM}_{2}^{2}$ \\
\hline & \multirow{3}{*}{ Quality } & Not cleaning the ring spinning machine & $\mathrm{FM}_{3}{ }^{1}$ \\
\hline & & Formation of neps due to short fibers or immature fibers & $\mathrm{FM}_{3}^{2}$ \\
\hline & & Insufficient cleaning of the flies & $\mathrm{FM}_{3}{ }^{3}$ \\
\hline & Production & $\begin{array}{l}\text { Not procuring cotton with the suitable-quality values for the ring spinning } \\
\text { facility }\end{array}$ & $\mathrm{FM}_{4}{ }^{1}$ \\
\hline \multirow{32}{*}{ 离 } & $\begin{array}{l}\text { Failure of Press } \\
\text { Machine }\end{array}$ & Failure of hydraulic system & $\mathrm{FM}_{5}{ }^{1}$ \\
\hline & \multirow{4}{*}{$\begin{array}{l}\text { Failure at the blow room } \\
\text { line }\end{array}$} & Failure of automatic bundle opening machine & $\mathrm{FM}_{6}{ }^{1}$ \\
\hline & & Failure of the homogenous mixer & $\mathrm{FM}_{6}^{2}$ \\
\hline & & Carding machine failure & $\mathrm{FM}_{6}{ }^{3}$ \\
\hline & & Failure of the fiber cleaning machine & $\mathrm{FM}_{6}^{4}$ \\
\hline & \multirow{5}{*}{$\begin{array}{l}\text { Failure of the cord } \\
\text { preparation line }\end{array}$} & Failure of the draw frame machine & $\mathrm{FM}_{7}{ }^{1}$ \\
\hline & & Fiber winding around the rotating element of the combed cotton machine & $\mathrm{FM}_{7}^{2}$ \\
\hline & & Breakage of the belt at cording machine & $\mathrm{FM}_{7}^{3}$ \\
\hline & & Bearing failure at cording machine & $\mathrm{FM}_{7}^{4}$ \\
\hline & & Engine failure at cording machine & $\mathrm{FM}_{7}^{5}$ \\
\hline & \multirow{5}{*}{$\begin{array}{l}\text { Failure of the Unilap } \\
\text { machine }\end{array}$} & Failure of pneumatic system tube & $\mathrm{FM}_{8}{ }^{1}$ \\
\hline & & Deformation of the felts of the pneumatic system & $\mathrm{FM}_{8}{ }^{2}$ \\
\hline & & Breaking of the springs in the clutch system & $\mathrm{FM}_{8}{ }^{3}$ \\
\hline & & Distance setting failure & $\mathrm{FM}_{8}{ }^{4}$ \\
\hline & & Bearing failure & $\mathrm{FM}_{8}{ }^{5}$ \\
\hline & \multirow{6}{*}{$\begin{array}{l}\text { Failure of ring spinning } \\
\text { machine }\end{array}$} & Servo disk failure & $\mathrm{FM}_{9}{ }^{1}$ \\
\hline & & Robo-load failure & $\mathrm{FM}_{9}^{2}$ \\
\hline & & Doffer failure & $\mathrm{FM}_{9}{ }^{3}$ \\
\hline & & Motor failure & $\mathrm{FM}_{9}^{4}$ \\
\hline & & Failure of spindle system & $\mathrm{FM}_{9}{ }^{5}$ \\
\hline & & Failure of pulling system & $\mathrm{FM}_{9}{ }^{6}$ \\
\hline & Carding machine failure & Not replacing the card clothing & $\mathrm{FM}_{10}{ }^{1}$ \\
\hline & $\begin{array}{l}\text { Cot grinding machine } \\
\text { failure }\end{array}$ & Grinding setting failure & $\mathrm{FM}_{11}{ }^{1}$ \\
\hline & \multirow{2}{*}{ Air conditioning failure } & Motor failure & $\mathrm{FM}_{12}{ }^{1}$ \\
\hline & & Front filter failure & $\mathrm{FM}_{12}{ }^{2}$ \\
\hline & \multirow{7}{*}{ Winder failure } & Failure of bobbin changer's mechanic element & $\mathrm{FM}_{13}{ }^{1}$ \\
\hline & & Failure of bobbin changer's holder & $\mathrm{FM}_{13}{ }^{2}$ \\
\hline & & Bobbin changer setting failure & $\mathrm{FM}_{13}{ }^{3}$ \\
\hline & & Suction fan motor bearing failure & $\mathrm{FM}_{13}{ }^{4}$ \\
\hline & & Suction fan motor winding failure & $\mathrm{FM}_{13}{ }^{5}$ \\
\hline & & Setting failure of the mechanical element in the spindle & $\mathrm{FM}_{13}{ }^{6}$ \\
\hline & & Deformation failure in the spindle & $\mathrm{FM}_{13}{ }^{7}$ \\
\hline
\end{tabular}


Table 7. The possible failure modes and the root causes for the ring spinning yarn production process (Cont.)

\begin{tabular}{|c|c|c|c|}
\hline Function & Failure Mode & Root Cause of the Failure & $\mathbf{F M}_{\mathrm{j}}^{\mathrm{i}}$ \\
\hline \multirow{15}{*}{ 馬 } & \multirow{8}{*}{ Fire Hazard in the Blowroom line } & Getting metal from the condenser & $\mathrm{FM}_{14}{ }^{1}$ \\
\hline & & Getting burning fiber from the condenser & $\mathrm{FM}_{14}^{2}$ \\
\hline & & Getting metal from the recycling machine & $\mathrm{FM}_{14}{ }^{3}$ \\
\hline & & Getting burning fiber from the recycling machine & $\mathrm{FM}_{14}{ }^{4}$ \\
\hline & & Electric arc in the press control panel & $\mathrm{FM}_{14}{ }^{5}$ \\
\hline & & Uncontrolled spreading of the sparks in the press welding process & $\mathrm{FM}_{14}{ }^{6}$ \\
\hline & & Fiber winding around the rollers of the carding machine & $\mathrm{FM}_{14}{ }^{7}$ \\
\hline & & Entry of foreign matter such as metal into the carding machine & $\mathrm{FM}_{14}{ }^{8}$ \\
\hline & Fire hazard in the carding machine & Fiber winding around the rollers of the combed cotton machine & $\mathrm{FM}_{15}{ }^{\mathrm{I}}$ \\
\hline & \multirow{2}{*}{ Fire Hazard in the ring spinning machine } & Electric arc failure in the ring spinning machine & $\mathrm{FM}_{16}^{1}$ \\
\hline & & Unfunctional switches in the ring spinning machine pulling area & $\mathrm{FM}_{16}^{2}$ \\
\hline & \multirow{2}{*}{ Fire hazard in the cording machine } & Electric arc failure in the cording machine & $\mathrm{FM}_{17}{ }^{\mathrm{I}}$ \\
\hline & & Fiber winding around the rollers of the cord pulling cylinder & $\mathrm{FM}_{17}{ }^{2}$ \\
\hline & Fire hazard in the winding machine & Electric arc failure in the winding machine & $\mathrm{FM}_{18}{ }^{1}$ \\
\hline & Fire hazard in the metal detector & Putting the cotton coming from the metal detector to recycling without any selection & $\mathrm{FM}_{19}{ }^{\mathrm{T}}$ \\
\hline
\end{tabular}

Table 8. The Occurrence (O) value, Severity (S) value and Detection value (D) for the each root causes

\begin{tabular}{|c|c|c|c|c|c|c|c|c|c|c|c|}
\hline $\mathrm{FM}_{\mathrm{j}}{ }^{\mathrm{i}}$ & $\mathbf{O}$ & $\mathbf{S}$ & D & $\mathrm{FM}_{\mathbf{j}}{ }^{\mathbf{i}}$ & $\mathbf{O}$ & $\mathbf{S}$ & D & $\mathbf{F M}_{\mathbf{j}}{ }^{\mathbf{i}}$ & $\mathbf{O}$ & $\mathbf{S}$ & D \\
\hline $\mathrm{FM}_{1}{ }^{1}$ & 7 & 10 & 10 & $\mathrm{FM}_{8}{ }^{1}$ & 2 & 8 & 4 & $\mathrm{FM}_{13}{ }^{6}$ & 3 & 4 & 4 \\
\hline $\mathrm{FM}_{1}^{2}$ & 6 & 10 & 10 & $\mathrm{FM}_{8}{ }^{2}$ & 2 & 8 & 4 & $\mathrm{FM}_{13}{ }^{7}$ & 3 & 4 & 4 \\
\hline $\mathrm{FM}_{1}^{3}$ & 8 & 10 & 5 & $\mathrm{FM}_{8}{ }^{3}$ & 2 & 8 & 4 & $\mathrm{FM}_{14}{ }^{1}$ & 3 & 10 & 7 \\
\hline $\mathrm{FM}_{1}^{4}$ & 7 & 10 & 10 & $\mathrm{FM}_{8}^{4}$ & 2 & 8 & 4 & $\mathrm{FM}_{14}^{2}$ & 3 & 10 & 7 \\
\hline $\mathrm{FM}_{2}{ }^{1}$ & 8 & 5 & 5 & $\mathrm{FM}_{8}{ }^{5}$ & 2 & 8 & 4 & $\mathrm{FM}_{14}{ }^{3}$ & 5 & 10 & 7 \\
\hline $\mathrm{FM}_{2}^{2}$ & 8 & 5 & 5 & $\mathrm{FM}_{9}{ }^{1}$ & 2 & 2 & 4 & $\mathrm{FM}_{14}{ }^{4}$ & 5 & 10 & 7 \\
\hline $\mathrm{FM}_{3}{ }^{1}$ & 3 & 8 & 5 & $\mathrm{FM}_{9}{ }^{2}$ & 2 & 2 & 4 & $\mathrm{FM}_{14}{ }^{5}$ & 1 & 10 & 7 \\
\hline $\mathrm{FM}_{3}{ }^{2}$ & 8 & 8 & 5 & $\mathrm{FM}_{9}{ }^{3}$ & 2 & 2 & 4 & $\mathrm{FM}_{14}{ }^{6}$ & 1 & 10 & 7 \\
\hline $\mathrm{FM}_{3}{ }^{3}$ & 8 & 8 & 3 & $\mathrm{FM}_{9}{ }^{4}$ & 3 & 7 & 4 & $\mathrm{FM}_{14}{ }^{7}$ & 2 & 10 & 7 \\
\hline $\mathrm{FM}_{4}{ }^{1}$ & 8 & 10 & 5 & $\mathrm{FM}_{9}{ }^{5}$ & 2 & 2 & 4 & $\mathrm{FM}_{14}{ }^{8}$ & 2 & 10 & 7 \\
\hline $\mathrm{FM}_{5}{ }^{1}$ & 3 & 7 & 2 & $\mathrm{FM}_{9}{ }^{6}$ & 2 & 2 & 4 & $\mathrm{FM}_{15}{ }^{1}$ & 3 & 10 & 7 \\
\hline $\mathrm{FM}_{6}{ }^{1}$ & 3 & 7 & 2 & $\mathrm{FM}_{10}{ }^{1}$ & 1 & 10 & 4 & $\mathrm{FM}_{16}{ }^{1}$ & 5 & 3 & 7 \\
\hline $\mathrm{FM}_{6}{ }^{2}$ & 3 & 7 & 2 & $\mathrm{FM}_{11}{ }^{1}$ & 1 & 10 & 4 & $\mathrm{FM}_{16}{ }^{2}$ & 10 & 7 & 9 \\
\hline $\mathrm{FM}_{6}^{3}$ & 4 & 3 & 2 & $\mathrm{FM}_{12}{ }^{1}$ & 3 & 7 & 4 & $\mathrm{FM}_{17}{ }^{1}$ & 5 & 3 & 7 \\
\hline $\mathrm{FM}_{6}{ }^{4}$ & 3 & 7 & 4 & $\mathrm{FM}_{12}{ }^{2}$ & 3 & 7 & 4 & $\mathrm{FM}_{17}{ }^{2}$ & 5 & 3 & 7 \\
\hline $\mathrm{FM}_{7}{ }^{1}$ & 4 & 3 & 4 & $\mathrm{FM}_{13}{ }^{1}$ & 3 & 3 & 4 & $\mathrm{FM}_{18}{ }^{1}$ & 2 & 5 & 7 \\
\hline $\mathrm{FM}_{7}^{2}$ & 3 & 4 & 4 & $\mathrm{FM}_{13}{ }^{2}$ & 3 & 3 & 4 & $\mathrm{FM}_{19}{ }^{1}$ & 10 & 10 & 9 \\
\hline $\mathrm{FM}_{7}^{3}$ & 2 & 8 & 4 & $\mathrm{FM}_{13}{ }^{3}$ & 3 & 3 & 4 & & & & \\
\hline $\mathrm{FM}_{7}^{4}$ & 2 & 8 & 4 & $\mathrm{FM}_{13}{ }^{4}$ & 2 & 6 & 4 & & & & \\
\hline $\mathrm{FM}_{7}{ }^{5}$ & 2 & 8 & 4 & $\mathrm{FM}_{13}{ }^{5}$ & 2 & 6 & 4 & & & & \\
\hline
\end{tabular}

Table 9. RPN and ranking for root causes of failure

\begin{tabular}{|c|c|c|c|c|c|c|c|c|}
\hline $\mathbf{F M}_{i}{ }^{\mathrm{i}}$ & RPN & Ranking & $\mathbf{F M}_{\mathrm{i}}{ }^{\mathbf{1}}$ & RPN & Ranking & $\mathbf{F M}_{\mathrm{i}}{ }^{\mathrm{i}}$ & RPN & Ranking \\
\hline $\mathrm{FM}_{1}^{1}$ & 700 & 2 & $\mathrm{FM}_{8}{ }^{1}$ & 64 & 16 & $\mathrm{FM}_{13}{ }^{6}$ & 48 & 17 \\
\hline $\mathrm{FM}_{1}^{2}$ & 600 & 4 & $\mathrm{FM}_{8}^{2}$ & 64 & 16 & $\mathrm{FM}_{13}{ }^{7}$ & 48 & 17 \\
\hline $\mathrm{FM}_{1}{ }^{3}$ & 400 & 5 & $\mathrm{FM}_{8}{ }^{3}$ & 64 & 16 & $\mathrm{FM}_{14}{ }^{1}$ & 210 & 8 \\
\hline $\mathrm{FM}_{1}^{4}$ & 700 & 2 & $\mathrm{FM}_{8}^{4}$ & 64 & 16 & $\mathrm{FM}_{14}{ }^{2}$ & 210 & 8 \\
\hline $\mathrm{FM}_{2}$ & 200 & 9 & $\mathrm{FM}_{8}{ }^{5}$ & 64 & 16 & $\mathrm{FM}_{14}{ }^{3}$ & 350 & 6 \\
\hline $\mathrm{FM}_{2}^{2}$ & 200 & 9 & $\mathrm{FM}_{9}^{1}$ & 16 & 22 & $\mathrm{FM}_{14}{ }^{4}$ & 350 & 6 \\
\hline $\mathrm{FM}_{3}{ }^{1}$ & 120 & 12 & $\mathrm{FM}_{9}{ }^{2}$ & 16 & 22 & $\mathrm{FM}_{14}{ }^{5}$ & 70 & 15 \\
\hline $\mathrm{FM}_{3}{ }^{2}$ & 320 & 7 & $\mathrm{FM}_{9}{ }^{3}$ & 16 & 22 & $\mathrm{FM}_{14}{ }^{6}$ & 70 & 15 \\
\hline $\mathrm{FM}_{3}{ }^{3}$ & 192 & 10 & $\mathrm{FM}_{9}^{4}$ & 84 & 14 & $\mathrm{FM}_{14}{ }^{7}$ & 140 & 11 \\
\hline $\mathrm{FM}_{4}{ }^{1}$ & 400 & 5 & $\mathrm{FM}_{9}{ }^{5}$ & 16 & 22 & $\mathrm{FM}_{14}{ }^{8}$ & 140 & 11 \\
\hline $\mathrm{FM}_{5}{ }^{\mathrm{I}}$ & 42 & 18 & $\mathrm{FM}_{9}{ }^{6}$ & 16 & 22 & $\mathrm{FM}_{15}$ & 210 & 8 \\
\hline $\mathrm{FM}_{6}{ }^{1}$ & 42 & 18 & $\mathrm{FM}_{10}{ }^{1}$ & 40 & 19 & $\mathrm{FM}_{16}{ }^{\mathrm{I}}$ & 105 & 13 \\
\hline $\mathrm{FM}_{6}^{2}$ & 42 & 18 & $\mathrm{FM}_{11}{ }^{1}$ & 40 & 19 & $\mathrm{FM}_{16}{ }^{2}$ & 630 & 3 \\
\hline $\mathrm{FM}_{6}{ }^{3}$ & 24 & 21 & $\mathrm{FM}_{12}{ }^{1}$ & 84 & 14 & $\mathrm{FM}_{17}{ }^{1}$ & 105 & 13 \\
\hline $\mathrm{FM}_{6}{ }^{4}$ & 84 & 14 & $\mathrm{FM}_{12}{ }^{2}$ & 84 & 14 & $\mathrm{FM}_{17}{ }^{2}$ & 105 & 13 \\
\hline $\mathrm{FM}_{7}{ }^{1}$ & 48 & 17 & $\mathrm{FM}_{13}{ }^{1}$ & 36 & 20 & $\mathrm{FM}_{18}{ }^{1}$ & 70 & 15 \\
\hline $\mathrm{FM}_{7}^{2}$ & 48 & 17 & $\mathrm{FM}_{13}{ }^{2}$ & 36 & 20 & $\mathrm{FM}_{19} 1$ & 900 & 1 \\
\hline $\mathrm{FM}_{7}^{3}$ & 64 & 16 & $\mathrm{FM}_{13}{ }^{3}$ & 36 & 20 & & & \\
\hline $\mathrm{FM}_{7}^{4}$ & 64 & 16 & $\mathrm{FM}_{13}{ }^{4}$ & 48 & 17 & & & \\
\hline $\mathrm{FM}_{7}^{5}$ & 64 & 16 & $\mathrm{FM}_{13}{ }^{5}$ & 48 & 17 & & & \\
\hline
\end{tabular}




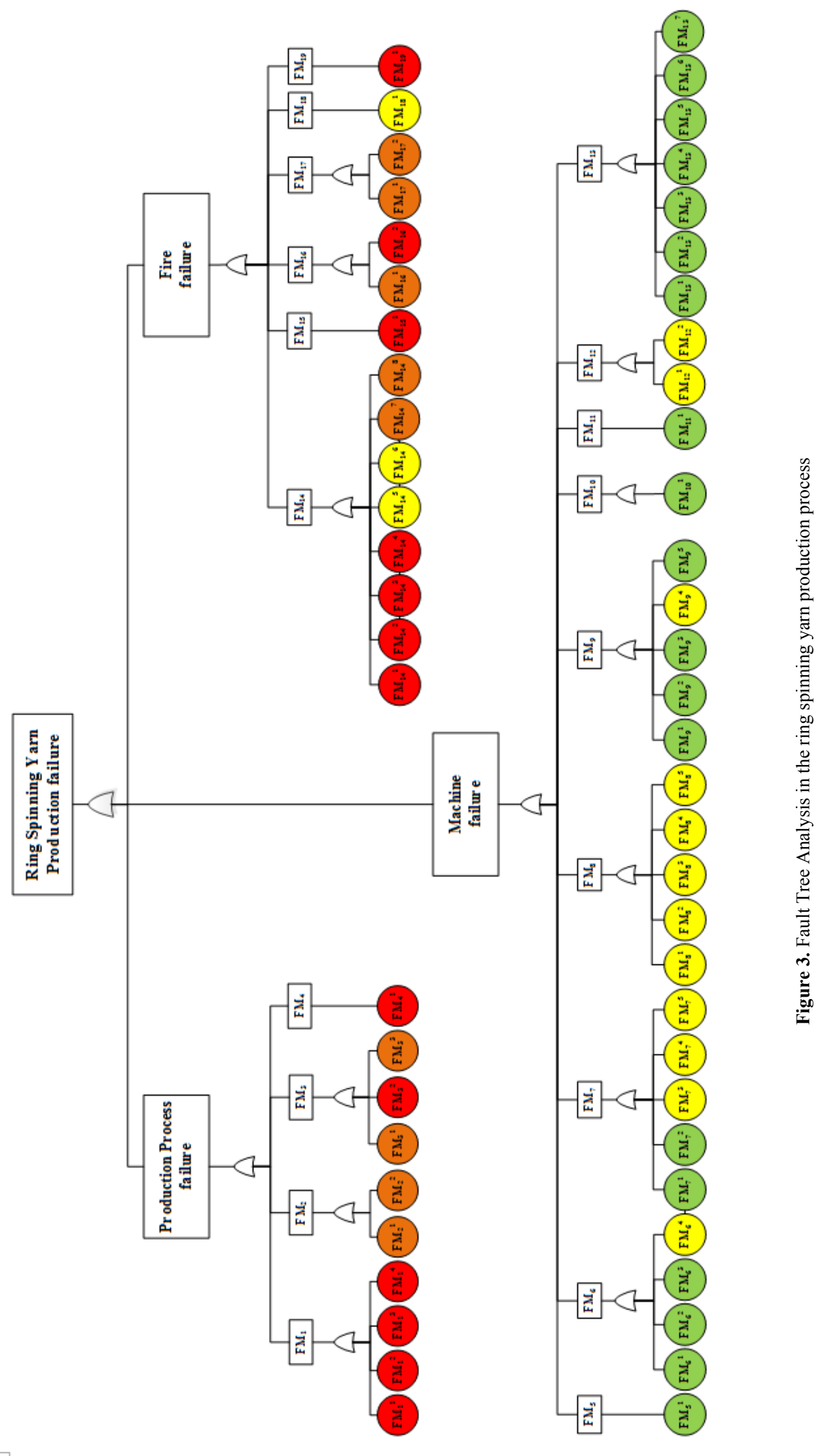




\section{REFERENCES}

1. Mikulak RJ, McDermott R, Beauregard M. 2008. The basics of $F M E A$. New York:CRC Press.

2. Küçük M, Güner M. 2014. The determination of 2nd quality and export surpluses evaluation efficiency of apparel companies with the methods of performance matrix and fuzzy logic. Tekstil ve Konfeksiyon 24(4), 386-392.

3. Küçük M, Güner M. 2015. Bir konfeksiyon işletmesinde süreç analizi yolu ile verimlilik artırma çalıșması. Tekstil ve Mühendis 22(98), 33-41.

4. Güner M, İşler M. 2013. The effect of model change processes on the overall equipment effectiveness in clothing production. Tekstil ve Konfeksiyon 23(3), 297-302.

5. Burduk A, Krenczyk D. 2017. June, Risk assessment in a parallel production system with the use of FMEA method and linguistic variables, In IFIP International Conference on Computer Information Systems and Industrial Management, Cham.:Springer, 10244, 379-390.

6. Press D. 2003. Guidelines for Failure Mode and Effects Analysis (FMEA), for Automotive, Aerospace, and General Manufacturing Industries. USA:CRC Press.

7. Peddada K. 2014. Risk Assessment and Control, Governance \& Control in Finance \& Banking: A New Paradigm for Risk \& Performance", pp:95-112.

8. Hiles A. 2010. The definitive handbook of business continuity management. UK:John Wiley \& Sons.

9. Sette S, Van Langenhove L. 2002. Optimising the fibre-to-yarn production process: finding a blend of fibre qualities to create an optimal price/quality yarn. Autex Research Journal 2(2), 257-263.

10. Militký J, Kovačič V, Rubnerova J. 2002. Influence of thermal treatment on tensile failure of basalt fibers. Engineering Fracture Mechanics 69(9), 1025-1033.

11. Sette S, Boullart L, Van Langenhove L, Kiekens P. 1997. Optimizing the fiber-to-yarn production process with a combined neural network/genetic algorithm approach. Textile Research Journal 67(2), 84-92.

12. Arain FA, Tanwari A, Hafiz-Ur-Rehman S. 2012. Statistical modeling for the effect of rotor speed, yarn twist and linear density on production and quality characteristics of rotor spun yarn. Mehran University Research Journal of Engineering and Technology 31(1), $119-128$

13. Özgüney AT, Dönmez Kretzschmar S, Özçelik G, Özerdem A. 2008. The comparison of cotton knitted fabric properties made of compact and conventional ring yarns before and after the printing process. Textile Research Journal 78(2), 138-147.

14. Dönmez Kretzschmar S, Özgüney AT, Özçelik G, Özerdem A. 2007. The comparison of cotton knitted fabric properties made of compact and conventional ring yarns before and after the dyeing process. Textile Research Journal 77(4), 233-241.

15. van der Werf HM, Turunen L. 2008. The environmental impacts of the production of hemp and flax textile yarn. Industrial Crops and Products 27(1), 1-10.

16. Şahin D. 2015. Türkiye ve Çin'in tekstil ve hazır giyim sektöründe rekabet gücünün analizi. Akademik Baklş 47, 155-171.

17. Uğurlu AA, Tuncer İ. 2017. Türkiye'de sanayi ve hizmet sektörlerinin büyüme ve istihdama katkıları: girdi çıktı analizi. Dokuz Eylül Üniversitesi İktisadi ve İdari Bilimler Fakültesi Dergisi 32(1), 131-165.

18. Wu X, Chen L, Zhou Y, Ding X. 2016. Research in risk assessment for textile and apparel and propose a future research agenda with a conceptual framework. International Journal of Productivity and Quality Management 17(3), 273-288.

19. Malik N, Maan AA, Pasha TS, Akhtar S, Ali T. 2010. Role of hazard control measures in occupational health and safety in the textile industry of Pakistan. Pakistan Journal of Agricultural Sciences 47(1), 72-76.

20. Khan WA, Mustaq T, Tabassum A. 2014. Occupational health, safety and risk analysis. International Journal of Science, Environment and Technology, 3(4), 1336-1346.

21. Guidelines for Chemical Process Quantitative Risk Analysis. 2009. 2nd ed., CCPS, American Institute of Chemical Engineers.

22. Lees FP, Mannan S. 2005. Lees' loss prevention in the process industries: hazard identification, assessment and control, vol. 1. UK:Elsevier, 234.

23. Wells G, Wardman M, Whetton C. 1993. Preliminary safety analysis. Journal of loss prevention in the process industries 6(1), 47-60.

24. Ericson CA. 2015. Hazard analysis techniques for system safety. New Jersey:John Wiley \& Sons.

25. IEC 60812:2006: Analysis techniques for system reliability Procedure for failure mode and effects analysis (FMEA), Retrieved from https://webstore.iec.ch/publication/3571, (Date of access: 10 July 2018).

26. Flaus JM. 2013. Risk analysis: socio-technical and industrial systems. New Jersey:John Wiley \& Sons, 153-309.

27. Beyene TD, Geremew Gebeyehu S, Mengistu AT. 2018. Application of failure mode effect analysis (FMEA) to reduce downtime in a textile share company. Journal of Engineering, Project \& Production Management 8(1), 40-46.

28. Küçük M, İşler M, Güner M. 2016. An application of the FMEA method to the cutting department of a clothing company. Tekstil ve Konfeksiyon 26(2), 205-212.

29. Paired E, Swadeshi AH, Shokohyar S. 2017. Analyzing the enhancement of production efficiency using FMEA through simulation-based optimization technique: A case study in apparel manufacturing. Cogent Engineering 4(1), 1284373.

30. Kumar G. 2015. March, Cycle time reduction for T-shirt manufacturing in a textile industry using lean tools. In Innovations in Information, Embedded and Communication Systems (ICIIECS), IEEE, 1-6.

31. Kaewsom P, Rojanarowan N. 2014. The application of FMEA to reduce defective rate from broken filament defects in the direct spin drawing process. IOSR Journal of Engineering 4(5), 55-58.

32. Özyazgan V. 2014. FMEA analysis and implementation in a textile factory producing woven fabric. Tekstil ve Konfeksiyon 24(3), 303308.

33. Liu HC, Liu L, Liu N. 2013. Risk evaluation approaches in failure mode and effects analysis: A literature review. Expert Systems with Applications 40(2), 828-838.

34. De Queiroz Souza R, Álvares AJ. 2008. FMEA and FTA analysis for application of the reliability centered maintenance methodology: case study on hydraulic turbines. In ABCM Symposium Series in Mechatronics, 803-812.

35. Khaiyum S, Kumaraswamy YS. 2014. An effective method for the identification of potential failure modes of a system by integrating FTA and FMEA. In ICT and Critical Infrastructure: Proceedings of the 48th Annual Convention of Computer Society of India, Springer, Cham., Vol:1, 679-686. 
36. Khaiyum S, Kumaraswamy YS. 2014. Integration of FMEA and FTA for effective failure management in real time embedded projects. Integrated Journal of British 1(3), 12-25.

37. Zhang YF, Zhou RB, Yang JM, Zhang Z. 2014. Application of FTAFMEA method in fault diagnosis of tracked vehicle. Advanced Materials Research 940, 112-115.

38. Martins LE, Gorschek T. 2017. Requirements engineering for safety-critical systems: overview and challenges. IEEE Software 34(4), 49-57.

39. IEC 61025:2006, Fault tree analysis (FTA), Retrieved from https:// webstore.iec.ch/publication/4311, (Date of access: 10 July 2018). 